\title{
Pengaruh Financial Distress, Total Asset Turnover, dan Audit Tenure pada Pemberian Opini Going Concern
}

\author{
Abdul Gani Damanhuri ${ }^{1}$ \\ Fakultas Ekonomi dan Bisnis \\ Universitas Udayana, Indonesia
}

\author{
I Made Pande Dwiana Putra2 \\ Fakultas Ekonomi dan Bisnis \\ Universitas Udayana, Indonesia
}

Surel : gani.damanhuri98@gmail.com

\section{ABSTRAK}

Tujuan dari penelitian ini ialah memperoleh bukti empiris terjait pengaruh financial distress, total asset turnover, dan audit tenure pada pemberian opini going concern. Penelitian berlokasi pada perusahaan yang terdaftar di Bursa Efek Indonesia (BEI) khususnya sektor manufaktur periode 2015-2018. Teknik pengumpulan sampel menggunakan metode purprosive sampling diperoleh 23 perusahaan untuk dijadikan sampel dengan 4 tahun pengamatan sehingga didapatkan jumlah sampel sebanyak 92 sampel. Hipotesis diujikan menggunakan teknik analisis regresi logistik. Hasil pengujian mengungkapkan bahwa financial distress berpengaruh signifikan positif pada pemberian opini going concern. Berikutnya TAT dan audit tenure berpengaruh negatif pada pemberian opini going concern.

Kata Kunci: Financial Distress; Total Asset Turnover; Audit Tenure; Opini Going Concern.

\section{The Effect of Financial Distress, Total Asset Turnover, and Audit Tenure on Going Concern Opinion}

\section{ABSTRACT}

The purpose of this study is to obtain empirical evidence of the influence of financial distress, total asset turnover, and audit tenure on going concern opinion. Research located on the Indonesia Stock Exchange (BEI) especially for the manufacturing sector for the period 2015-2018. The sample determined by using purprosive sampling technique, and obtained 23 companies as a samples with 4 years of observation so the total of sample it's 92 samples. The hypothesis was tested using logistic regression analysis techniques. The test results reveal that financial difficulties have a significant effect on the implementation of opinion that is happening. Distributed TAT and tenure audits are negative on going concern opinion.

Keywords: $\quad$ Financial Distress; Total Asset Turnover; Tenure Audit; Going Concern Opinion.

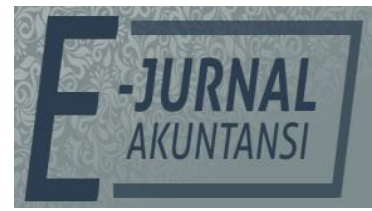

e-ISSN 2302-8556

Vol. 30 No. 9

Denpasar, September 2020

Hal. 2392-2402

DOI:

10.24843/EJA.2020.v30.i09.p17

PENGUTIPAN:

Damanhuri, A. G. \& Putra, I M. P. D. (2020). Pengaruh

Financial Distress, Total Asset

Turnover, dan Audit Tenure pada Pemberian Opini Going

Concern. E-Jurnal Akuntansi, 30(9), 2392-2402

RIWAYAT ARTIKEL: Artikel Masuk: 22 April 2020 Artikel Diterima: 29 Juli 2020

Artikel dapat diakses : https://ojs.unud.ac.id/index.php/Akuntansi/index 


\section{PENDAHULUAN}

Masa depan perusahaan (going concern) atau biasa dikenal kontinuitas, adalah asumsi akuntansi yang digunakan untuk memprediksi keberlangsungan hidup suatu entitas bisnis pada jangka waktu yang tidak terbatas (Pratomo, 2018). Kontinuitas dari suatu merupakan hal penting yang harus dijaga oleh perusahaan, berbagai upaya dilakukan agar perusahaan tersebut tidak diragukan keberlangsunganya oleh investor. Salah satu upaya yang dilakukan auditor untuk memberikan penilaian terkait masa depan perusahaan adalah dengan mengungkapkan masalah going concern (IAPI, 2015). Opini going concern akan diterbitkan apabila selama masa pemeriksaan terdapat tanda-tanda yang memiliki kemungkinan untuk menghambat keberlanjutan perusahaan. . Bursa Efek Indonesia (BEI) menyebutkan ada 15 perusahaan yang terancam delisting atau dihapuskan dari pasar modal. Direktur Penilaian Perusahaaan BEI mengungkapkan, alasan perusahaaan tersebut disuspensi adalah tidak memenuhi ketentuan sebagai perusahaan publik. Selain itu, beberapa perusahaan tersebut tidak dapat menjaga going concern perusahaaan. Kepercayaan perusahaan terhadap KAP akan sangat dipertaruhkan apabila pemberian opini tidak relevan dengan keadaan perusahaan yang semestinya (Saputra \& Kustina, 2018). Terapat beberapa faktor yang mempengaruhi keberlangsungan suatu entitas bisnis, faktor tersebut akan dibahas sebagai variabel bebas dalam penelitian ini.

Penelitian Ginting, (2018) mengungkapkan bahwa Total Asset Turnover dapat mewakili efsiensi aset dalam mendorong kemajuan bisnis perusahaan, dimana rasio ini memperlihatkan volume penjualan yang akan mengungkapkan bagaimana perputaran total aset perusahaan. Artinya, seberapa baik pengelolaan total aktiva untuk menciptakan penjualan. Apabila perputarannya lambat, dapat disimpulkan bahwa aktiva perusahaan belum mampu mengelola aktiva dengan baik untuk melakukan penjualan. Semakin besar rasio TAT, dapat disimpulkan bahwa kemampuan perusahaan dalam mengelola total aktiva semakin baik dalam menciptakan laba sesuai yang diharapkan.

Ketidakmampuan suatu perusahaan dalam mengelola asetnya dengan baik dapat mengakibatkan perusahaan mengalami financial distress (kesulitan keuangan). Kondisi keuangan yang tidak stabil atau kritis dikenal dengan istilah financial distress (Noor, 2016). Menurut penelitian Setiadamayanthi \& Wirakusuma, (2016) disebutkan bahwa financial distress tidak berpengaruh pada kecenderungan opini going concern. Saputra \& Kustina, (2018) menyatakan bahwa salah satu bentuk dari financial distress adalah kondisi kas yang minus, rasio keuangan yang kurang baik, dan tidak mampu membayar hutang, semua elemen tersebut nantinya dapat terlihat pada laporan keuangan yang disajikan, hal ini dapat mempengaruhi principal dan agen dalam membuat keputusan.

Auditor independen memiliki peran untuk menengahi perbedaan kepentingan diantara prinsipal dan agen. Menurut teori keagenan kepercayaan atau wewenang yang diberikan oleh prinsipal kepada agen harus diawasi oleh seorang auditor, karena dalam pelaksanaannya belum tentu agen menjalankan kewajibannya sebagaimana mestinya, bisa saja terjadi ketidakefisienan yang berdampak pada kondisi keuangan perusahaan. Oleh karenanya opini auditor penting untuk menjamin bahwa wewenang dan tugas yang dilakukan agen 
sudah dilakukan dengan sebaik-baiknya. Auditor diharuskan memberikan opini yang sesuai atau relevan, sehingga opini yang dikeluarkan auditor dapat mencerminkan keadaan perusahaan yang sebenarnya (Pradana et al, 2019).

Tingginya tenure auditor dengan perusahaan dikhawatirkan akan menurunkan kualitas opini yang dikeluarkan, hal ini biasa dikenal auit tenure (Gunawan, 2019). Audit tenure yang semakin panjang tentu saja akan memberikan benefit yang baik bagi auditor dari sisi material, akan tetapi dikhawatirkan akan menimbulkan hubungan emosional antara auditor engan perusahaan klien yang diinikasikan akan menurunkan independensi auditor dalam memberikan opininya (Gunawan, 2019).

Penelitian terdahulu yang membahas tentang opini going concern banyak dilakukan tetapi masih menunjukkan hasil yang berbeda di antaranya, Syahputra \& Yahya, (2017) menunjukkan bahwa audit tenure berpengaruh pada pemberian opini going concern. Hasil penelitian Arfansyah, (2017), mendukung penelitian sebelumnya yang menyatakan bahwa berdasarkan pengujian regresi logistik audit tenure berpengaruh terhadap pemberian opini going concern. Berbeda dengan penelitian sebelumnya, Mahdi, (2018) memberi kesimpulan bahwa audit tenure tidak berpengaruh terhadap pemberian opini going concern. Perbedaan temuan pada penelitian membuat peneliti melihat ada sebuah peluang untuk meneliti kembali terkait opini going concern secara lebih kompleks mengenai pengaruh financial distress, total asset turnover, dan audit tenure pada pemberian opini going concern.

Adapun kriteria perusahaan yang digunakan adalah merupakan sektor manufaktur di BEI periode tahun 2015-2018, perusahaan mengalami rugi yang tercantum dilaporan keuangan pada salah satu tahun dalam periode pengamatan 2015-2018 dan memiliki data-data yang dibutuhkan. Adapun alasan hanya digunakan sektor manufaktur adalah karena sektor manufaktur mendominasi perusahaan di Bursa Efek Indonesia (BEI) serta untuk memperkecil miunculnya resiko industrial efek yaitu resiko inustri yang berbeda. Kriteria tersebut sudah sesuai dengan penelitian sebelumnya antara lain Carey, P. \& Simnett, (2006).

Berdasarkan pada Teori keagenan menggambarkan perikatan antara pihak principal dan pihak agen, dimana keuanya mempunyai kepentingan masing-masing didalam sebuah organisasi, untuk pertama kalinya untuk petama kalinya teori agency dicetuskan oleh Jensen dan Mackling pada tahun 1976, dimana dismapaikan bahwa pihak principal yaitu yang memberi mandatkepada pihak lain yaitu agen, disampaikan bahwa agen diharuskan memberikan informasi yang terperinci dan relevan. Pada kenyataanya, agen tiak jarang menutup nutupi informasi bagi pihak principaldengan kata lain pihak principal tidak akan mudah mendapat informasi dari pihak agen. Faktor yang memicu hal tersebut adalah perbedaan kepentingan diantara keduanya sehingga menyebabkan pihak agen terkesan menahan informasi yang dibutuhkan oleh principal, (Dewi \& Suardikha, 1991).

Kondisi financial distress yang dialami perusahaan mendorong kemungkinan ia akan diberikan opini going concern dikarenakan dalam konisi pendanaan yang kurang stabil serta tidak memiliki kas yang cukup untuk menutupi hutang lancar serta menjalankan bisnisnya dengan kata lain hamper 
mengalami kebangkrutan. Penelitian Yuliyani \& Erawati, (2017) membuktikan bahwa hasil uji menggunakan rumus Altman Z-Score mengungkapkan bahwa financial distress berpengaruh positif pada pemberian opini going concern, hal ini senada dengan penemuan yang iungkapkan oleh Dewi \& Latrini, (2018). Berdasarkan pemaparan tersebut maka peneliti merumuskan hipotesis sebegai berikut.

$\mathrm{H}_{1}$ : Financial distress berpengaruh positif pada pemberian opini going concern.

Abadi et al., (2019) mengungkapkan bahwa total asset turnover yang dapat diproyeksikan dengan Rasio TAT. Teori keagenan menjelaskan dengan adanya konflik antara principal dan agen maka akan mendorong agen untuk melakukan segala cara agar kinerja nya terlihat maksimal dimata principal. Penelitian Pradika, (2018) menemukan bahwa total asset turnover berpengaruh dan signifikan terhadap opini going concern. Sesuai dengan pemaparan, peneliti mengajukan hipotesis sebagai berikut.

$\mathrm{H}_{2}$ : Total Asset Turnover berpengaruh negatif pada pemberian opini going concern.

Teori Keagenan menjelasakan bahwa terdapat pihak ketiga sebagai penengah dalam perbedaan kepentingan antara principal dan agen, Peran penengah tersebut dilakukan oleh auditor yang bertugas mengawasi dan memberikan opini atas laporan keuangan yang merupakan cermin kinerja dari manajemen. Tingginya tenure antara auditor dengan perusahaan klien dikhawatirkan akan menurunkan kualitas opini yang dikeluarkan. Menurut penelitian Arfansyah, (2017) menyatakan bahwa berdasarkan pengujian regresi logistik Lamanya perikatan antara auitor dengan perusahaan klien secara signifikan berpengaruh pada pemberian opini going concern. Berdasarkan pemaparan tersebut maka peneliti merumuskan hipotesis sebegai berikut.

$\mathrm{H}_{3}$ : Audite tenure berpengaruh negatif pada pemberian opini going concern.

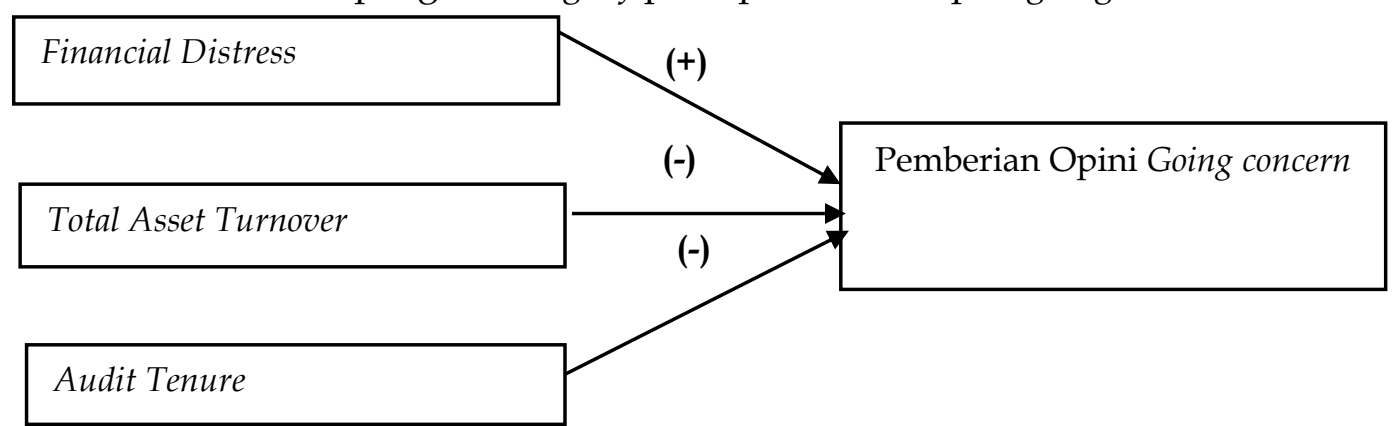

\section{Gambar 1. Desain Penelitian}

Sumber : Data Penelitian, 2020

\section{METODE PENELITIAN}

Penelitian dilakukan pada situs resmi Bursa Efek Indonesia (BEI) yaitu www.idx.co.id, dengan mengunduh laporan tahunan perusahaan, serta obyek yang menjadi focus penelitian ini adalah financial distress, total asset turnover, dan audit tenure pada pemberian opini going concern.

Variabel bebas dalam hal ini adalah pemberian opini going concern. Perusahaan yang mengandung opini going concern dalam laporan keuangannya akan diklasifikasikan dengan angka 1, selanjutnya bagi perusahaan yang tidak terindikasi menganung opini going concern dalam laporan keuangannya akan 
akan diklasifikasikan engan angka 0 . Klasifikasi ini sesuai dengan penelitian Carey, P. \& Simnett (2006), Jackson et al., (2008), dan Byusi \& Achany, (2018).

Kondisi financial distress dalam sebuah perusahaan dapat diprediksi menggunakan model prediksi kebangkrutan Altman. Fungsi diskriminan model Altman dirumuskan sebagai berikut (Putra, 2012).

$Z=1,2(X 1)+1,4(X 2)+3,3(X 3)+0,6(X 4)+0,999(X 5)$

Dimana:

$\mathrm{Z}=$ Altman Z-Score

$\mathrm{X} 1=$ (Current Assets - Current Liabilities) $/$ Total assets

$\mathrm{X} 2=$ Retained Earnings / Total assets

$\mathrm{X} 3=$ Earnings before Interest and Taxes / Total Assets

X4 = Market Value of Equity/ Total Liability

X5 $=$ Sales $/$ Total Asset

Apabila nilai $Z<1,81$ maka perusahaan diklasifikasikan sebagai bankrupt atau diprediksi akan mengalami kebangkrutan. Adapun jika $Z \geq 1,81$ maka perusahaan akan dikategorikan kedalam kelompok perusahaan non-bankrupt atau diprediksi tidak akan mengalami kebangkrutan (Nugroho et al., 2018).

Rasio total asset turnover digunakan untuk mengukur efektivitas suatu perusahaan dalam memutar aktiva yang dimiliki dalam rangka mendapatkan keuantungan yang maksimal Januarti \& Fitrianasari, (2008) mengungkapkan dimana rasio aktivitas yang tinggi nantinya akan mencermikan bahwa perusahaan telah mampu mngelola aset nya dengan baik terutama dalam melakukan kegiatan operasinya. Pengukuran total asset turnover menggunakan rumus berikut, Pengukuran ini sudah sesuai dengan pengukuran yang dilakukan (Setyarno et al., 2006).

\section{Penjualan Bersih \\ Total Asset Turnover $=$ Total Asset}

Pengukuran variabel audit tenure menggunakan variabel dummy, dimana angka 1 diberikan jika hubungan antara perusahaan klien dengan auditor yang $\geq 3$ tahun, dan 0 jika hubungan antara perusahaan klien dengan auditor yang sama $<3$ tahun (Arfansyah, 2017).

Penelitian ini menggunakan ata kuantitatif yang bersumber dari ata sekunder eksternal, dimana perolehan data didapatkan secara tidak langsung melainkan melalui perantara berupa dokumen atau informan lain (Sugiyono, 2017). Sumber data sekunder eksternal data dilakukan peneliti dengan mengutip dari laporan tahunan perusahaan melalui laman website www.idx.co.id.

Populasi dalam penelitian ini adalah seluruh perusahaan manufaktur yang terdaftar di Bursa Efek Indonesia periode 2015-2018. Pemilihan sample mengadopsi metode purposive sampling, yaitu metode pengumpulan sampel atas dasar kriteria tertentu untuk menghindari adanya bias akibat perbedaan yang signifikan. Adapun kriteria perusahaan yang menjadi sampel terpilih antara lain: Perusahaan manufaktur yang terdaftar di Bursa Efek Indonesia (BEI) selama periode 2015-2018. Perusahaan manufaktur yang menyajikan laporan tahunan (annual report) secara berturut-turut selama periode 2015-2018.

Pengumpulan data menggunakan metode dokumentasi. Adapun dokumen yang diamati yaitu laporan keuangan tahunan yang dipublikasikan 
oleh perusahaan sektor manufaktur tahun 2015-2018. Metode analisis yang digunakan dalam penelitian ini adalah analisis regresi logistik dan diolah menggunakan alat statistik SPSS. Adapun tahapan analisis dimulai dari statistik deskriptif, analisis regresi logistik, dan uji hipotesis penelitian.

Dalam penelitian ini teknik analisis regresi logistik digunakan karena variabel opini going concern sebagai variabel terikat merupakan variabel dummy. Persamaan regresi tersebut adalah sebagai berikut.

\begin{tabular}{|c|c|}
\hline $\mathrm{P}(\mathrm{Y})$ & : Pemberian opini going concern \\
\hline & : Nilai konstanta \\
\hline$\beta 1, \beta 2, \beta 3$ & : Koefisien regresi masing-masing faktor \\
\hline X1 & : Financial Distress \\
\hline $\mathrm{X} 2$ & : Total Asset Turnover \\
\hline X3 & : Audit Tenure \\
\hline$\varepsilon$ & : error \\
\hline
\end{tabular}

\section{HASIL DAN PEMBAHASAN}

Penelitian berlokasi pada perusahaan sektor manufaktur yang terdaftar I Bursa Efek Indonesia (BEI) periose 2015-2018. Berdasarkan kriteria yang ditentukan terdapat 23 perusahaan yang terpilih dan layak menjadi sampel penelitian. Dikarenakan periode pengamatan selama 4 tahun maka terdapat 92 sampel sudah resmi menjai sampel penelitian.

Analisis statistik deskriptif penelitian menjelaskan bagaimana karakteristik dari masing-masing variabel penelitian yang terdiri dari jumlah pengamatan, nilai minimum, nilai maksimum, nilai rata-rata dan standar deviasi. Tabel 1, berikut menunjukkan hasil analisis statistik deskriptif variabel penelitian ini.

Tabel 1. Hasil Statistik Deskripstif Variabel Penelitian

\begin{tabular}{lllllll}
\hline & $\mathrm{N}$ & Minimum & Maximum & Mean & Std. Deviation & Variance \\
\hline OGC & 92 & 0,00 & 1,00 & 0,2174 & 0,41473 & 0,172 \\
FD & 92 & 0,00 & 1,00 & 0,3478 & 0,47889 & 0,229 \\
TAT & 92 & 0,008 & 2,259 & 0,7918 & 0,55036 & 0,303 \\
AT & 92 & 0,00 & 1,00 & 0,4022 & 0,49302 & 0,243 \\
\hline
\end{tabular}

Sumber: Data Penelitian, 2020

Hasil uji untuk variabel opini going concern $(\mathrm{Y})$ memiliki nilai minimum 0 dan nilai maksimum 1 yang berarti bahwa varibel ini merupakan variabel dummy, dimana angka 0 merepresentasikan perusahaan yang tidak diberikan opini going concern dan angka 1 merupakan perusahaan yang sebaliknya.

Variabel $X_{1}$ menampilkan nilai terkecil 0 dan terbesar 1 . Keadaan ini mengindikasikan Financial Distress dikategorikan variabel dummy, adapun angka 1 merupakan perusahaan yang mengalami Financial Distress dan angka 0 merupakan perusahaan yang tidak mengalami Financial Distress. Variabel Total Asset Turnover menampikan nilai terkecil sebesar 0,008 dan nilai terbesar sebesar 2,259. Audit Tenure memiliki nilai terkecil sebesar 0,00 dan nilai terbesar sebesar 1. Adapun angka 1 merupakan kategori perusahaan yang perikatannya dengan 
auditor $\geq 3$ tahun sedangkan angka 0 merupakan perusahaan yang menggunakan jasa auditor yang sama $<3$ tahun.

Kelayakan model regresi dinilai menggunakan uji Homser and Lemeshow. Uji Homser and Lemeshow menguji hipotesis nol bahwa data empiris cocok atau sesuai dengan model (tidak ada perbedaan antara model dengan data sehingga model dikatakan fit). Jika nilai menunjukkan signifikan Uji Homser and Lemeshow lebih besar dari 0,05 maka hipotesis 0 diterima dan berarti model mampu memprediksi nilai observasinya. Pada Tabel 2, akan disajikan tabel uji Homser and Lemeshow.

Tabel 2. Hasil Uji Homser and Lemeshow

\begin{tabular}{llll} 
Step & Chi-square & df & Sig. \\
\hline 1 & 5,991 & 8 & 0,648 \\
\hline Sumber: Data Penelitian, 2020 & & & \\
Berdasarkan hasil analisis & pada & Tabel 2 & diperoleh bahwa nilai dari uji
\end{tabular}
Homser and Lemeshow yang diukur dengan nilai Chi Square sebesar 5,991 dengan nilai signifikansi sebesar 0,648 . Hal ini menunjukkan nilai signifikansi 0,648 > 0,05 sehingga dapat dikatakan bahwa model yang ada dapat memprediksi nilai observasinya.

Uji multikolinearitas bertujuan untuk menguji apakah model regresi ditemukan adanya korelasi antar variabel bebas, karena model regresi yang baik seharusnya tidak terjadi korelasi antara variabel bebas.

Tabel 3. Uji Multikolinearitas

\begin{tabular}{llll}
\hline & Model & Collinearity Statistics & Tolerance \\
$($ Constant $)$ & & VIF \\
\cline { 2 - 3 } & FD & 0,884 & 1,131 \\
TAT & 0,843 & 1,186 \\
AT & 0,947 & 1,056 \\
\hline
\end{tabular}

Sumber: Data Penelitian, 2020

Berdasarkan hasil uji multikolinearitas pada Tabel 3, variabel financial distress, total asset turnover dan audit tenure menunjukkan nilai tolerance $>0,1$ atau nilai $\mathrm{VIF}<10$. Oleh karena itu, dapat disimpulkan bahwa variabel bebas dalam penelitian ini terbebas dari multikolinearitas atau tidak ada korelasi antar variabel bebas.

Model ini dibentuk menggunakan nilai estimasi parameter pada Variabel dalam persamaan. Berdasarkan hasil Uji dapat digambarkan dalam Tabel 4, berikut ini.

Tabel 4. Rangkuman Analisis Regresi Logistik

\begin{tabular}{|c|c|c|c|c|c|c|c|c|}
\hline & \multirow[b]{2}{*}{$\mathrm{B}$} & \multirow[b]{2}{*}{ S.E. } & \multirow[b]{2}{*}{ Wald } & \multirow[b]{2}{*}{$\mathrm{df}$} & \multirow[b]{2}{*}{ Sig. } & \multicolumn{2}{|c|}{ 95\% C.I.for EXP(B) } \\
\hline & & & & & & & Lower & Upper \\
\hline \multirow[t]{4}{*}{ Step 1a } & FD & 1,270 & 0,621 & 4,188 & 1 & 0,041 & 1,055 & 12,014 \\
\hline & TAT & $-2,217$ & 0,840 & 6,959 & 1 & 0,008 & 0,021 & 0,566 \\
\hline & $\mathrm{AT}$ & $-1,462$ & 0,733 & 3,977 & 1 & 0,046 & 0,055 & 0,975 \\
\hline & Constant & $-0,085$ & 0,635 & 0,018 & 1 & 0,894 & & \\
\hline
\end{tabular}

Sumber: Data Penelitian, 2020 
Menurut hasil uji analisis linier berganda seperti yang ditampilkam pada Tabel 4, maka diproleh persamaan sebagai berikut.

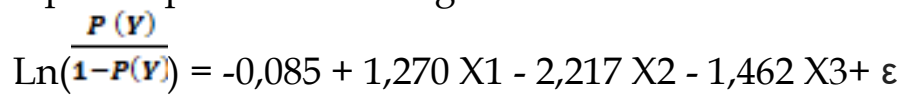

Nilai koefisien beta untuk X1 adalah 1,270, artinya setiap peningkatan financial distress sebesar 1 persen, secara langsung akan meningkatkan nilai probabilitas variabel dependen pemberian opini audit going concern. Koefisien beta untuk X2 adalah -2,217, artinya peningkatan rasio total asset turnover sebanyak 1 kali akan mengurangi probabilitas pemberian opini going concern. Koefisien beta X3 adalah $-1,462$, artinya peningkatan audit tenure sebanyak 1 tahun secara langsung akan menurunkan nilai probabilitas perusahaan memperoleh opini going concern sebanyak 1.462 kali.

Berdasarkan hasil Uji H1 iproleh hasil bahwa Variabel financial distress menunjukkan koefisien regresi positif sebesar 1,270 dengan tingkat signifikansi sebesar 0,041. Nilai signifikansi uji t untuk variabel financial distress sebesar 0,041 lebih kecil dari signifikansi 0,05 yang berarti hipotesis diterima. Jadi kesimpulan dari variabel financial distress berpengaruh positif terhadap pemberian opini going concern. Penelitian ini konsisten dengan Penelitian Yuliyani \& Erawati, (2017) yang berhasil menunjukkan hubungan yang positif antara financial distress dengan pemberian opini going concern.

Pengujian hipotesis kedua menunjukkan hasil bahwa variabel total asset turnover menunjukkan koefisien regresi negatif sebesar -2.217 dengan tingkat signifikansi sebesar 0,008. Nilai signifikansi uji t untuk variabel Total Asset Turnover sebesar 0,008 lebih kecil dari signifikansi 0,05 yang berarti hipotesis diterima.

Berdasarkan hasil Uji hipotesis ketiga memproleh hasil bahwa Variabel Audit Tenure menunjukkan koefisien regresi negatif sebesar -1,462 dengan tingkat signifikansi sebesar 0,046. Nilai signifikansi uji t untuk variabel Audit Tenure sebesar 0,046 lebih kecil dari signifikansi 0,05 yang berarti hipotesis diterima. Variabel audit tenure berpengaruh negatif terhadap pemberian opini going concern. Penelitian ini konsisten dengan Syahputra \& Yahya (2017) dan Arfansyah, (2017) yang berhasil menunjukkan hubungan yang negatif antara financial distress dengan pemberian opini going concern. Mengacu pada hasil pembahasan yang dilakukan sesuai hasil uji untuk hipotesis pertama, dimana hasil ini mendukung teori stakeholders dimana nilai perusahaan sangat ditentukan oleh kemampuan perusahaan dalam mengelola asset yang dimilikinya yang nantinya akan menentukan seberapa besar profit yang akan dibagikan bagi para pemegang saham. Sedangkan total asset turnover dan audit tenure berpengaruh negatif pada pemberian opini going concern.

Hasil penelitian terhadap hipotesis pertama dengan menggunakan regresi logistik mendukung teori stakeholders dimana nilai perusahaan sangat ditentukan oleh kemampuan perusahaan dalam mengelola asset yang dimilikinya yang nantinya akan menentukan seberapa besar profit yang akan dibagikan bagi para pemegang saham. Perusahaan yang mengalami financial distress berkemungkinan untuk diberikan opini going concern karena perusahaan tidak memiliki arus kas yang cukup untuk membayar kewajiban lancarnya atau menjalankan usahanya, sehingga perusahaan berkemungkinan besar untuk 
bangkrut. Maka dapat di katakan bahwa perusahaan yang mengalami kesulitan keuangan yang diindikasikan memiliki nilai Z-Score yang kecil, memiliki kemungkinan diberikan opini audit going concern yang semakin besar.

Hasil hipotesis kedua ini sekaligus mendukung teori keagenan yang menjelaskan bahwa agen akan melakukan segala cara agar terlihat memiliki kinerja yang maksimal dimata principal salah satunya dengan cara memperoleh laba yang maksimal atas sejumlah aset yang dimiliki perusahaan. Semakin besar perbandingan laba dengan aset maka perusahaan telah mampu menggunakan sumber daya asetnya untuk digunakan mencari keuntungan tercermin pada kinerja manajemen yang efektif dan efisien dalam mengelola asetnya. yang artinya Semakin tinggi rasio TAT maka kemungkinan memperoleh opini going concern akan semakin rendah.

Hasil hipotesis ketiga mendukung teori keagenan yang menyatakan bahwa terdapat pihak ketiga dalam perbedaan kepentingan antara principal dan agen dalam hal ini auditor.

\section{SIMPULAN}

Berdasarkan hasil analisis yang diuraikan, maka simpulan yang diperoleh sebagai berikut: 1) Financial Distress berpengaruh positif pada pemberian opini going concern. Hal tersebut menunjukkan semakin tinggi kemungkinan perusahaan mengalami Financial Distress, maka semakin tinggi pula kemungkinan perusahaan tersebut memperoleh opini going concern. 2) Total Asset Turnover berpengaruh negatif pada pemberian opini Going Concern. Hal tersebut menunjukkan semakin tinggi rasio TAT maka kemungkinan memperoleh opini going concern akan semakin rendah. Sebaliknya, jika rasio TAT semakin rendah maka peluang mendapatkan opini audit going concern akan semakin besar. 3) Audit Tenure berpengaruh negatif pada pemberian opini Going Concern pada perusahaan manufaktur yang terdaftar di Bursa Efek Indonesia selama periode 2015-2018.

Maka dari itu semakin tinggi tenure atau hubungan antara auditor dengan perusahaan klien maka kemungkinan memperoleh opini going concern akan semakin kecil. Sebaliknya, semakin kecil atau singkat hubungan antara auditor dengan perusahaan klien maka kemungkinan memperoleh opini Going Concern akan semakin besar.

Berdasarkan simpulan yang telah diuraikan, maka dapat disampaikan beberapa saran sebagai berikut: 1) Bagi peneliti selanjutnya diharapkan menambah variabel bebas untuk menambah prediksi faktor yang mempengaruhi pemberian opini Going Concern dan bagi penelitian selanjutnya diharapkan mengamati dalam periode jangka waktu yang lebih lama dari penelitian ini sehingga bisa memperbanyak sampel penelitian. 2) Pengamatan dilakukan hanya selama 4 perioe, akan menjadi lebih baik apabila pada penelitian selanjutnya menggunakan sektor yang lebih banyak di perusahaan yang terdaftar di Bursa Efek Indonesia, sehingga bisa memperluas manfaat penelitian. 3) Bagi perusahaan yang terdaftar di Bursa Efek Indonesia (BEI) diharapkan agar lebih teliti dan lebih berhati-hati dalam mengambil keputusan serta berfokus pada faktor-faktor penting yang dapat memicu penerimaan opini going concern pada laporan keuangan. 


\section{REFERENSI}

Abadi, K., Purba, D. M. \& Fauzia, Q. (2019). the Impact of Liquidity Ratio, Leverage Ratio, Company Size and Audit Quality on Going Concern Audit Opinion. Jurnal Akuntansi Trisakti. 6(1), p. 69. doi: 10.25105/jat.v6i1.4871.

Arfansyah, R. (2017). Pengaruh Audit Quality, Audit Tenure, dan Profitabilitas Terhadap Opini Audit Going Concern pada Perusahaan Manufaktur yang Terdaftar di BEI Periode 2012-2015. Jurnal Akuntansi USU. doi: https://ejournal.unsrat.ac.id/index.php/gc/article/view/20097.

Byusi, H. \& Achany, F. (2018). Determinan Opini Audit Going Concern (Studi Empiris pada Perusahaan Real Estate dan Property yang terdaftar di BEI Tahun 2013-2015). Jurnal Akuntansi, Fakultas Ekonomi dan Bisnis, Universitas Muhammadiyah. p. 3, pp. 13-28. Doi : 10.23917/reaksi.v3i1.5552.

Carey, P. and Simnett, R. (2006). Audit Partner Tenure and Audit Quality, Accounting Review. 653-76. p. doi: https://www.jstor.org/stable/4093109.

Dewi, \& Latrini, M. Y. (2018). Pengaruh Financial Distress dan Debt Default pada Opini Audit Going Concern. E-Jurnal Akuntansi Universitas Udayana, 22. p. 1223. doi: 10.24843/EJA.2018.v22.i02.p15.

Dewi, E. C. \& Suardikha, S. (1991). Pengaruh Independensi, Locus of Control dan Motivasi Kerja Pada Kinerja Auditor Auditor di Kantor Akuntan Publik Provinsi Bal. E-Jurnal Akuntansi Universitas Udayana. 42(2), pp. 189-191. doi: 10.11428/jhej1987.42.189.

Ginting, W. A. (2018). Analisis Faktor-Faktor Yang Mempengaruhi Opini Audit Going Concern. Jurnal Rekayasa keuangan, Syariah dan Audit, 5(1), pp. 45-53. doi: https://core.ac.uk/267886349.

Gunawan, S. (2019). Going Concern Audit Opinion and Corporate Governance In Manufacturing Companies Listed in BEI. International Journal of Stability, Education, and Global Economic. 2(3). https://doi.org/10.1234/ijsegce.v2i3.118.

IAPI, (2015). Standar Profesional Akuntan Publik.

Jackson, A. B., Roebuck, P. \& Moldrich, M. (2008). Mandatory Audit Firm Rotation and Audit Quality. Managerial Auditing Journal. 23(5), pp. 420-437. doi: $10.1108 / 02686900810875271$.

Mahdi. (2018). Pengaruh Kualitas Audit, Audit Tenure, Opini Audit Sebelumnya dan Pertumbuhan Perusahaan terhadap Audit Going Concern (Studi Empiris Perusahaan Manufaktur Terdapat di Bursa Efek Indonesia Periode 2011-2014). Jurnal Akuntansi Fakultas Ekonomi Dan Bisnis Universitas Muhammadiyah Surakarta. doi: http:/ / eprints.ums.ac.id/id/eprint/51660.

Noor, D. I. (2016). Pengaruh Financial Distress, Leverage, Profitabilitas, dan Likuiditas terhadap Penerimaan Opini Audit Going Concern. (Studi Empiris Pada Perusahaan yang Terdaftar di Jakarta Islamic Index Tahun 2011-2014). Disability and Rehabilitation. 20(1), pp. 87-108. doi: 10.1080/14768320500230185.

Nugroho, L., Nurrohmah, S. \& Anasta, L. (2018). Faktor-Faktor Yang Mempengaruhi Opini Audit Going Concern. Jurnal SIKAP (Sistem 
Informasi, Keuangan, Auditing Dan Perpajakan). doi: 10.32897/sikap.v2i2.79.

Pradana \& Kusuma. (2019). Pengaruh Independensi, Locus Of Control, Kompleksitas Tugas dan Orientasi Tujuan Terhadap Kinerja Auditor. Jurnal Sains, Akuntansi dan Manajemen. 1(4), p. doi: https://doi.org/10.1234/jsam.v4i1.74.

Pradika. (2018). Analisis Pengaruh Auditor Change, Ukuran KAP, Kondisi Keuangan, Profitabilitas dan Pertumbuhan Perusahaan terhadap Asumsi Audit Going Concern pada Perusahan Manufaktur yang Terdaftar di BEI Tahun 2012-2016. Jurnal Fakultas Ekonomi Universitas Maritim Raja Ali Haji Tanjungpinang, Kepulauan Riau. doi: https://doi.org/10.225/kr.10.1.1-62.

Pratomo, A. (2018). Analisis Pengaruh Auditor Change, Ukuran KAP, Kondisi Keuangan, Profitabilitas dan Pertumbuhan Perusahaan terhadap Asumsi Audit Going Concern pada Perusahan Manufaktur yang Terdaftar di BEI Tahun 2012-2016. Jurnal Fakultas Ekonomi Universitas Maritim Raja Ali Haji Tanjungpinang, Kepulauan Riau. doi.org/10.2356225/kr.8.2.73

Saputra, E. and Kustina, K. T. (2018) 'Analisis Pengaruh Financial Distress, Debt Default, Kualitas Auditor, Auditor Client Tenure, Opinion Shopping dan Disclosure, Terhadap Penerimaan Opini Audit Going Concern Pada Perusahaan Manufaktur Yang Terdaftar Di Bursa Efek Indonesia. Jurnal Akuntansi dan Bisnis Undiknas. 10(1), pp. 51-62. http:/ / dx.doi.org/10.22225/kr.10.1.712.51-62.

Setiadamayanthi, N. and Wirakusuma, M. (2016). Pengaruh Auditor Switching Dan Financial Distress Pada Opini Audit Going Concern. E-Jurnal Akuntansi Universitas Udayana, 15(3), pp. 1654-1681.

Setyarno, E. B., Januarti, I. \& Faisal. (2006). Pengaruh Kualitas Audit, Kondisi Keuangan Perusahaan, Opini Audit Tahun Sebelumnya, Pertumbuhan Perusahaan Terhadap Opini Audit Going Concern. Simposium Nasional Akuntansi IX.

Sugiyono. (2017). Metode Penelitian Kuantitatif, Kualitatif dan R\&D. Bandung: PT PT Alfabet. doi: 10.1017/CBO9781107415324.004.

Syahputra, F. \&Yahya (2017). Pengaruh Audit Tenure , Audit Delay , Opini Audit Tahun Sebelumnya dan Opinion Shopping Terhadap Penerimaan Opini Audit Going Concern pada Perusahaan Manufaktur yang Terdaftar di Bursa Efek Indonesia Tahun 2013-2015. Jurnal Ilmiah Mahasiswa Ekonomi Akuntansi (JIMEKA), 2(3). E-ISSN 2581-1002.

Yuliyani \& Erawati. (2017). Pengaruh Financial Distress, Proftabilitas, Leverage dan Likuiditas Pada Opini Audit Going Concern. E-Jurnal Akuntansi Universitas Udayana. 19(2), pp. 1490-1520. doi: ISSN: 2302-8556. 